\title{
Ammonia emissions from livestock production in Chile: an inventory and uncertainty analysis
}

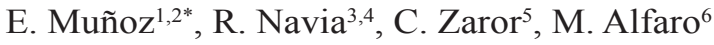 \\ ${ }^{I}$ Center for Sustainability Research, Universidad Andres Bello, Santiago, Chile. \\ ${ }^{2}$ Doctorado en Ingeniería, Universidad de La Frontera, Temuco, Chile. \\ ${ }^{3}$ Departamento de Ingeniería Química \& Núcleo Científico Tecnológico en Biorrecursos, Universidad de La \\ Frontera, Temuco, Chile. \\ ${ }^{4}$ Centre for Biotechnology and Bioengineering (CeBiB), Universidad de La Frontera, Temuco, Chile. \\ ${ }^{5}$ Departamento de Ingeniería Química, Universidad de Concepción, Concepción, Chile. \\ ${ }^{6}$ Instituto de Investigaciones Agropecuarias INIA Remehue, Osorno, Chile *Corresponding author: edmundo. \\ munoz@unab.cl
}

\begin{abstract}
The objective of this work was to quantify the country's $\mathrm{NH}_{3}$ emissions from livestock production. This calculation was based on the mass flow of total ammoniacal nitrogen (TAN). The analysis was performed for all 15 geographical regions in Chile. The definition of livestock subcategories was based on data from the Chilean Agriculture and Forestry Census as well as technical reports published by the Chilean National Statistics Institute. Significant differences were observed among the sources of livestock emissions in Chile's regions, and there was high variability depending on the degree of livestock confinement. In 2013, the total calculated emissions were $69.1 \mathrm{kt} \mathrm{NH} /$ year $( \pm 31.1)$. The O'Higgins Region had the highest $\mathrm{NH}_{3}$ emissions in Chile, representing $45 \%$ of the total. In terms of livestock production, $45 \%$ of the emissions were generated by pigs, $22 \%$ by poultry, $16 \%$ by cattle, $11 \%$ by equines and $4 \%$ by sheep. Emissions from the TAN that was available during manure and slurry management and the degree of animal confinement were the primary sources of uncertainty. This uncertainty could be greatly reduced by developing regional emission factors and by including the degree of animal confinement in Chile's national statistics such as the Agriculture, Livestock and Forestry Census.
\end{abstract}

Keywords: Ammonia, livestock, emissions, nitrogen losses, uncertainty

\section{Introduction}

Gas emissions inventories are commonly used to calculate total national emissions and identify major emission sources to develop abatement policies (Webb and Misselbrook, 2004). The first ammonia emissions inventories for livestock production were calculated by multiplying the quantity of livestock by an emission factor (EF) for each type of animal. According to Webb and Misselbrook (2004), 
this approach does not allow for the identification of significant differences in the potential for $\mathrm{NH}_{3}$ emissions because of differences in diets, and therefore in the excretion of nitrogen, and differences in livestock or the use of manure in different countries or regions. In general, emissions vary widely from country to country depending on the different livestock sectors present, that is, cattle, sheep, pigs and poultry. These variations are generated by the proportions of each class of livestock and their respective nitrogen excretion and emissions (EAA, 2009), differences in agricultural practices such as livestock housing and manure storage and application (Martínez-Lagos et al., 2010) as well as climate differences (EAA, 2009). The source of $\mathrm{NH}_{3}$ emissions from manure is nitrogen that is excreted by livestock. Typically, more than half of the nitrogen excreted by mammalian livestock is urine, and between 65 and $85 \%$ of the urine is in the form of urea and other relatively mineralized compounds. The urease enzyme rapidly hydrolyzes urea into ammonium carbonate $\left(\left(\mathrm{NH}_{4}\right)_{2} \mathrm{CO}_{3}\right)$ and ammonium ion $\left(\mathrm{NH}_{4}^{+}\right)$, providing the primary source of $\mathrm{NH}_{3}$ (EEA, 2009). Ammoniacal nitrogen $\left(\mathrm{NH}_{4}{ }^{+} \mathrm{N}\right)$ and other compounds, including uric acid, quickly decompose into $\mathrm{NH}_{4}^{+}-\mathrm{N}$. By contrast, most of the $\mathrm{N}$ in mammalian livestock excrement (fecal matter) is not easily degradable (EEA, 2009). Only a small percentage of this $\mathrm{N}$ is present as urea or $\mathrm{NH}_{4}^{+}$, and the $\mathrm{NH}_{3}$ emissions are therefore fairly small for estimating the total ammoniacal nitrogen (TAN) in pastures or housing. However, TAN may be mineralized from fecal $\mathrm{N}$ during manure storage and soil application. A recent study quantified the $\mathrm{N}$ mineralized rates in permanent grassland fertilized with dairy slurry. In this study the $\mathrm{N}$ mineralization ranged between 320-344 $\mathrm{kg} \mathrm{NH}_{4}^{+}-\mathrm{N} \mathrm{ha}^{-1} \mathrm{yr}^{-1}$ (Martínez-Lagos et al., 2015). Conversely, poultry only produce manure that is primarily made up of uric acid. This compound, along with other labile compounds, can be degraded into $\mathrm{NH}_{4}^{+}-\mathrm{N}$ after being hydrolyzed into urea (Groot Koerkamp, 1994).

Livestock is the greatest source of $\mathrm{NH}_{3}$ emissions, primarily from manure. In Europe is estimated that $80-90 \%$ of all agricultural emissions result from animal production (EAA, 2009). In particular, this sector represents $96 \%$ of total French ammonia emissions (Gac et al., 2007), and in Spain, livestock is responsible for $78 \%$ of agricultural $\mathrm{NH}_{3}$ emissions (Gallego et al., 2009). In the United States, Doorn et al. (2002) estimated that approximately $80 \%$ of ammonia emissions are associated with livestock waste. The most recent studies have replaced emissions sources by animals with specific sources for different stages of manure management. In this work, we estimate the $\mathrm{NH}_{3}$ emissions generated by livestock in Chile by using a model with a mass flow approach for the total ammoniacal nitrogen throughout a manure management system.

\section{1. $\mathrm{NH}_{3}$ emissions from livestock}

Several studies have been conducted to estimate the $\mathrm{NH}_{3}$ emissions from livestock and agricultural sources. According to the estimates of Carew (2010), the 2002 livestock emissions represented 64\% of Canada's total emissions, with cattle and pigs comprising the largest sources. In addition, that study provided evidence of marked differences in $\mathrm{NH}_{3}$ contributions from livestock sources in the eastern and western regions of Canada. In the west, cattle were the primary source of emissions, with $49 \%$, followed by pigs with $12 \%$; in the east, pigs comprised the primary livestock source with $27 \%$, followed by dairy cows with $25 \%$. In the U.K., Webb and Misselbrook (2004) estimated that approximately $60 \%$ of livestock emissions came from cattle, and 18 and $12 \%$ were generated by poultry and pigs, respectively. $\mathrm{Xu}$ et al. (2015) performed a study in China, and they 
estimated that livestock was responsible for $47.5 \%$ of total emission in Chine; Livestock categories with large $\mathrm{NH}_{3}$ emissions include poultry, pigs, cattle and sheep, which contribute $34 \%, 29 \%, 29 \%$ and $4 \%$, respectively. Based on a complete inventory of $\mathrm{NH}_{3}$ emissions in Galicia (Spain), Gallego et al. (2009) found that livestock was responsible for $89.4 \%$ of $\mathrm{NH}_{3}$ emissions, and fertilizers were only responsible for 7\%. Similar to Gallego et al. (2009), other studies have reported agricultural and livestock emissions of $\mathrm{NH}_{3}$. In Athens, Greece, Sotiropoulou et al. (2004) estimated that livestock production accounted for $73 \%$ of $\mathrm{NH}_{3}$ emissions in that region, and MartínezLagos et al. (2010) estimated that in Chile's Los Ríos and Los Lagos regions, emissions from livestock totaled $6.2 \mathrm{kt} \mathrm{NH}_{3}-\mathrm{N}$ in 2007. In the latter study, 85\% of the emissions came from cattle (Table 1).

Table 1. $\mathrm{NH}_{3}$ emissions of different countries and regions

\begin{tabular}{|c|c|c|c|c|c|}
\hline Country & Scope & $\begin{array}{c}\text { Inventory } \\
\text { year }\end{array}$ & $\begin{array}{c}\text { Emissions } \\
\text { (kt NH} H_{3} \text { year) }\end{array}$ & Sector & Reference \\
\hline China & National & 2010 & $\begin{array}{c}10,700 \\
5,100\end{array}$ & $\begin{array}{l}\text { Total } \\
\text { Livestock }\end{array}$ & Xu et al., 2015 \\
\hline Greece & $\begin{array}{l}\text { National } \\
\text { Athens }\end{array}$ & $\begin{array}{c}-- \\
1996\end{array}$ & $\begin{array}{l}95 \\
13\end{array}$ & $\begin{array}{l}\text { Total } \\
\text { Agriculture }\end{array}$ & $\begin{array}{l}\text { Buijsman et al., } 1987 \\
\text { Sotiropoulou et al., } 2004\end{array}$ \\
\hline UK & National & 1984 & 355 & $\begin{array}{l}\text { Livestock } \\
\text { Grassland }\end{array}$ & Ryden et al., 1987 \\
\hline UK & National & 1999 & 224 & Total & Pain et al., 1999 \\
\hline UK & National & -- & 207 & Livestock & $\begin{array}{l}\text { Webb and Misselbrook, } \\
2004\end{array}$ \\
\hline Canada & National & 2002 & $\begin{array}{l}306 \\
110\end{array}$ & $\begin{array}{l}\text { Livestock } \\
\text { Fertilizers }\end{array}$ & Carew, 2010 \\
\hline Spain & Galicia & 2001 & 70 & Total & Gallego et al., 2009 \\
\hline French & National & 2007 & 425 & Livestock & Gac et al., 2007 \\
\hline Chile & $\begin{array}{l}\text { Los Lagos y Los } \\
\text { Ríos }\end{array}$ & 2007 & $7.5^{*}$ & Livestock & $\begin{array}{l}\text { Martínez-Lagos et al., } \\
(2010)\end{array}$ \\
\hline
\end{tabular}

*Expressed as $\mathrm{kt} \mathrm{NH}_{3}$ from $\mathrm{kt} \mathrm{NH}_{3}-\mathrm{N} \cdot(17 / 14)$

\subsection{Methods for determining $\mathrm{NH}_{3}$ emissions from livestock}

According to Webb (2001), livestock N excretion can be calculated by using three different methods. The first is by multiplying the total population of animals in each livestock category by an individual excreted $\mathrm{N}$ value that is associated with each type of animal. The second, which uses a "bottom up" approach, estimates $\mathrm{N}$ excretion from the balance between the typical ingested $\mathrm{N}$ in the diet and the output into livestock products (milk, meat, etc.). The third method, which is a "top down" method, uses national data about the $\mathrm{N}$ in the animal content and production statistics and the $\mathrm{N}$ concentration in livestock products (meat, milk, eggs and wool). Similarly, the European Environment Agency (EEA, 2009) proposes three different levels for estimating $\mathrm{NH}_{3}$ emissions. In the first method, the annual average number of animals in each livestock category is multiplied by a default 
emission factor. The EF includes emissions during ruminant grazing and the application of manure for all livestock categories. In this method, the animal characterization must group livestock that are subject to similar management types. The EF proposed for each livestock category may be found in Sotiropoulou et al. (2004) and EEA (2009). The second method uses a mass flow approach based on the concept of total ammoniacal nitrogen (TAN) flow during each stage of manure management. In the first step, the subcategories of homogeneous livestock are defined in terms of the type of diet, excretions, and age/ weight range of each animal group. This information is used to calculate $\mathrm{N}$ excretions by animal (Nex; $\mathrm{kg}$ $\mathrm{N}$ animal ${ }^{-1}$ ). When there is insufficient national data for this calculation, the methodology recommends the method described by the IPCC (2006) for Nex estimations. Subsequently, the proportion of Nex that is deposited in housing, yards or pastures is calculated, and it is based on the number of days during the year in which the animals are confined. The Nex value in each stage is multiplied by the proportion of TAN (Table 2) to obtain the quantity of TAN deposited during each stage of manure management. The quantities of TAN available in each manure stage (solid and slurry) are multiplied by specific emission factors to obtain the $\mathrm{NH}_{3}-\mathrm{N}$ losses from volatilization. Table 2 shows the EFs and TAN for the primary livestock categories. Because the immobilization or loss of TAN reduces the potential for $\mathrm{NH}_{3}-\mathrm{N}$ emissions during storage and subsequent dispersion, the model takes into account the amount of TAN that is immobilized in organic material when the manure is managed as a solid. In addition, the method allows for an estimation of the quantity of TAN that is converted into $\mathrm{N}_{2} \mathrm{O}$ and $\mathrm{NO}$ and $\mathrm{N}_{2}$, by using emission factors for each gas.

The third method is more precise than the second one and does not have any limitations, to the extent that it can provide demonstrable estimations (EEA, 2009). Emissions can be calculated for a large number of livestock categories, as long as data are available. In this method, the level 2 calculation model can be used as long as there are specific emission factors for each region or if abatement measures are included.

\section{Methodology}

\subsection{Selection of emission sources}

Nitrogen excretions (Nex) and the subsequent emissions of $\mathrm{NH}_{3}-\mathrm{N}$ vary by livestock species (cattle, pigs, and sheep, among others) (EEA, 2009) and by the diet of the livestock (Webb, 2001). Within one livestock species, there are large differences between animals that are kept for different purposes (dairy cows vs. beef cattle). Therefore, it is necessary when possible to disaggregate the livestock by the type of species and production (EEA, 2009). In this sense, the primary livestock sources established by the EMEP/EEA guide (2009) have been used to select the emission factors. However, a classification has been developed on the basis of Chilean statistical data availability (INE 2007; INE 2013a, b, c, d, e) and IPCC (2006) recommendations for emissions from livestock and manure management. Based on this data, 32 classes of animals were identified. The analysis was performed for Chile's 15 regions, from the Arica and Parinacota Region in the north to the Magallanes and Antarctica Region in the south. Approximately 53\% of the productive soil surface in Chile correspond to natural and improved grasslands, and the agricultural soils account for almost $10 \%$ of soil surface, being concentrated in Central zone (Muñoz et al., 2010). Volcanic soils are widespread in southern Chile accounting for $60 \%$ of the nation arable land. They are characterised by low nutrient availability, high 
phosphorus (P) fixation capacity, high organic matter $(\mathrm{OM})$ content and a $\mathrm{pH}$-dependent cation exchange capacity (Alfaro et al., 2006). Mediterranean zone of
Chile there are mainly neutral to alkaline soils, where on high-pH soils may occur nutrient deficiencies such as boron $(\mathrm{B})$, copper $(\mathrm{Cu})$, iron $(\mathrm{Fe})$, manganese $(\mathrm{Mn})$ and zinc (Zn) (Nájera et al., 2015).

Table 2. $\mathrm{NH}_{3}-\mathrm{N}$ emission factors from manure management and percentages of TAN (adapted from EEA, 2009)

\begin{tabular}{|c|c|c|c|c|}
\hline \multirow{2}{*}{ Livestock } & \multirow{2}{*}{$\begin{array}{l}\text { TAN } \\
(\%)\end{array}$} & \multirow{2}{*}{$\begin{array}{l}\text { Manure } \\
\text { management }\end{array}$} & \multicolumn{2}{|c|}{ EF (\% of TAN) } \\
\hline & & & Slurry & Solid manure \\
\hline \multirow{5}{*}{ Dairy cows } & \multirow{5}{*}{0.6} & Housing & $0.20(0.10-0.40)$ & $0.19(0.10-0.38)$ \\
\hline & & Yard & $0.30(0.15-0.60)$ & $0.30(0.15-0.60)$ \\
\hline & & Storage & $0.20(0.10-0.40)$ & $0.27(0.14-0.54)$ \\
\hline & & Spreading & $0.55(0.28-0.75)$ & $0.79(0.40-0.85)$ \\
\hline & & Grazing & $0.10(0.05-0.20)$ & $0.10(0.05-0.20)$ \\
\hline \multirow{5}{*}{ Other cattle } & \multirow{5}{*}{0.6} & Housing & $0.20(0.10-0.40)$ & $0.19(0.10-0.38)$ \\
\hline & & Yard & $0.53(0.27-0.75)$ & $0.53(0.27-0.75)$ \\
\hline & & Storage & $0.20(0.10-0.40)$ & $0.27(0.14-0.54)$ \\
\hline & & Spreading & $0.55(0.28-0.75)$ & $0.79(0.40-0.85)$ \\
\hline & & Grazing & $0.06(0.03-0.12)$ & $0.06(0.03-0.12)$ \\
\hline \multirow{4}{*}{$\begin{array}{l}\text { Fattening pigs } \\
(8-110 \mathrm{~kg})\end{array}$} & \multirow{4}{*}{0.7} & Housing & $0.28(0.14-0.56)$ & $0.27(0.14-0.54)$ \\
\hline & & Yard & $0.53(0.27-0.75)$ & $0.53(0.27-0.75)$ \\
\hline & & Storage & $0.14(0.07-0.28)$ & $0.45(0.23-0.90)$ \\
\hline & & Spreading & $0.40(0.20-0.80)$ & $0.81(0.41-0.90)$ \\
\hline \multirow{3}{*}{$\begin{array}{l}\text { Sows } \\
\text { (to } 8 \mathrm{~kg} \text { ) }\end{array}$} & \multirow{3}{*}{0.7} & Housing & $0.22(0.11-0.44)$ & $0.27(0.14-0.54)$ \\
\hline & & Storage & $0.14(0.07-0.28)$ & $0.53(0.27-0.75)$ \\
\hline & & Spreading & $0.29(0.15-0.58)$ & $0.45(0.23-0.90)$ \\
\hline \multirow{5}{*}{ Sheep and goats } & \multirow{5}{*}{0.5} & Housing & & $0.22(0.11-0.44)$ \\
\hline & & Yard & & $0.75(0.38-0.90)$ \\
\hline & & Storage & & $0.28(0.14-0.56)$ \\
\hline & & Spreading & & $0.90(0.45-0.95)$ \\
\hline & & Grazing & & $0.09(0.05-0.18)$ \\
\hline \multirow{4}{*}{ Horses, mules, and asses } & \multirow{4}{*}{0.7} & Housing & & $0.22(0.11-0.44)$ \\
\hline & & Storage & & $0.35(0.18-0.70)$ \\
\hline & & Spreading & & $0.90(0.45-0.95)$ \\
\hline & & Grazing & & $0.35(0.18-0.70)$ \\
\hline \multirow{3}{*}{ Laying hens } & \multirow{3}{*}{0.7} & Housing & & $0.41(0.21-0.82)$ \\
\hline & & Storage & & $0.14(0.07-0.28)$ \\
\hline & & Spreading & & $0.69(0.35-0.80)$ \\
\hline \multirow{3}{*}{ Broilers } & \multirow{3}{*}{0.7} & Housing & & $0.28(0.14-0.56)$ \\
\hline & & Storage & & $0.17(0.09-0.34)$ \\
\hline & & Spreading & & $0.66(0.33-0.75)$ \\
\hline
\end{tabular}




\subsection{Emissions calculation}

The calculation was performed by using a mass flow approach to find the total ammoniacal nitrogen (TAN) throughout each stage of manure management (EEA, 2009). An approach based on the total $\mathrm{N}$ was not considered because the calculation of $\mathrm{NH}_{3}-\mathrm{N}$ is also used by the IPCC (2006) to estimate $\mathrm{N}_{2} \mathrm{O}$ emissions. The definition of livestock subcategories was based on data from the 2007 Chilean Agriculture and Forestry Census (INE, 2007) and from technical reports published by the Chilean National Statistics Institute (INE), including the Bovine Livestock Survey (INE, 2013e) and the annual report on Poultry (INE, 2013b) and Pig Farms (INE, 2013a). The quantity of nitrogen excreted (Nex) by each animal is the product of the rate of $\mathrm{N}$ excretion $(\mathrm{kg} \mathrm{N}(1000 \mathrm{~kg}$ animal) $)^{-1}$ day $^{-1}$ ) that is obtained from the IPCC (2006) and the average mass by type of animal. Data provided by Luengo and Morales (1999) were used to obtain the average mass of beef cattle, and IPCC (2006) data that had been recommended for Latin America were used for pigs, sheep, goats, equine animals, and poultry. In the absence of data, nitrogen excretions were obtained from Gallego et al. (2009). To estimate the nitrogen excretion loads in housing and during grazing, the degree of confinement results (the time during which the cows are not grazing) presented by Carrillo et al. (2011) were used for central-southern Chile (Metropolitan, Maule, and Bio-Bio regions); for southern Chile (Los Ríos and Los Lagos regions), we used findings by Smith et al. (2002). The emission factors of $\mathrm{NH}_{3}-\mathrm{N}, \mathrm{N}_{2} \mathrm{O}, \mathrm{NO}$ and $\mathrm{N}_{2}$ that were generated by the TAN that was available during slurry and manure storage were obtained from the EMEP/EEA guide (2009) and the IPCC (2006). The fractions of TAN mineralization in the slurry $\left(\mathrm{f}_{\min }=0.1\right)$ and its immobilization in the solid manure $\left(f_{\text {imm }}=0.0067\right)$ were used to estimate the TAN mineralization and immobilization during storage (EEA, 2009). These emissions were calculated because during this stage, $\mathrm{N}_{2} \mathrm{O}$, $\mathrm{NO}$ and $\mathrm{N}_{2}$ emissions are generated from TAN, thereby reducing the availability of nitrogen in the application phase. The emission factors used for $\mathrm{N}_{2} \mathrm{O}$, NO and $\mathrm{N}_{2}$ were those recommended by the EMEP/EEA guide (2009) for each type of manure. Figure 1 is a diagram of the nitrogen routes that were included in the methodology for estimating $\mathrm{NH}_{3}$ emissions. Table 2 summarizes the primary emission factors considered in this study. The emissions generated in yards were not included because of a lack of information, and for this reason, the manure was distributed between grazing and housing. All the information was processed in a Microsoft Excel 2011 spreadsheet, generating a matrix of 101 columns and 35 rows. The rows correspond to the different livestock classes, and the columns contain the inventory data, IPCC (2006) and EEA (2009) equations, and calculations of the different sources of uncertainty. The spreadsheet was replicated for each region of Chile, and the totals for each region were added together to create national data. 
Table 3. Matrix used to assess the data source quality (Gallego et al., 2009)

\begin{tabular}{|c|c|c|c|c|c|}
\hline & 1 & 2 & 3 & 4 & 5 \\
\hline RELIABILITY & $\begin{array}{l}\text { Verified data } \\
\text { based on } \\
\text { measurement }\end{array}$ & $\begin{array}{l}\text { Verified data partly } \\
\text { based on } \\
\text { assumptions or } \\
\text { non-verified }{ }^{\mathrm{b}} \text { data } \\
\text { based on } \\
\text { measurements }\end{array}$ & $\begin{array}{l}\text { Non-verified data } \\
\text { partly based on a } \\
\text { hypothesis }\end{array}$ & $\begin{array}{c}\text { Qualified } \\
\text { estimation (e.g., } \\
\text { industrial, } \\
\text { agriculture) }\end{array}$ & $\begin{array}{l}\text { Non-qualified } \\
\text { estimate of } \\
\text { unknown data } \\
\text { origin }\end{array}$ \\
\hline $\begin{array}{l}\text { Uncertainty factor } \\
\left(\mathrm{U}_{1}\right)\end{array}$ & 1 & 1.05 & 1.1 & 1.2 & 1.5 \\
\hline $\begin{array}{l}\text { TEMPORAL } \\
\text { CORRELATION }\end{array}$ & $\begin{array}{l}\leq 3 \text { years difference } \\
\text { from reference year }\end{array}$ & $\begin{array}{l}\leq 6 \text { years difference } \\
\text { from reference year }\end{array}$ & $\begin{array}{l}\leq 10 \text { years } \\
\text { difference from } \\
\text { reference year }\end{array}$ & $\begin{array}{l}\leq 15 \text { years } \\
\text { difference from } \\
\text { reference year }\end{array}$ & $\begin{array}{l}\leq 15 \text { years } \\
\text { difference from } \\
\text { reference year }\end{array}$ \\
\hline $\begin{array}{l}\text { Uncertainty factor } \\
\left(\mathrm{U}_{2}\right)\end{array}$ & 1 & 1.03 & 1.1 & 1.2 & 1.5 \\
\hline $\begin{array}{l}\text { GEOGRAPHICAL } \\
\text { CORRELATION }\end{array}$ & $\begin{array}{l}\text { Data from area } \\
\text { under study }\end{array}$ & $\begin{array}{l}\text { Average data from } \\
\text { a larger area that } \\
\text { includes the area of } \\
\text { study }\end{array}$ & $\begin{array}{l}\text { Data from a smaller } \\
\text { area than the area } \\
\text { under study or from } \\
\text { a similar area }{ }^{\mathrm{c}}\end{array}$ & & $\begin{array}{c}\text { Data from an } \\
\text { unknown or } \\
\text { distinctly different } \\
\text { area }\end{array}$ \\
\hline $\begin{array}{l}\text { Uncertainty factor } \\
\left(\mathrm{U}_{3}\right)\end{array}$ & 1 & 1.01 & 1.02 & & 1.1 \\
\hline
\end{tabular}

${ }^{a}$ Verified data: published in public environmental reports of companies, official statistics; ${ }^{b}$ Non-verified data: personal information by letter, fax or e-mail; ' Similarity expressed in terms of environmental legislation

\subsection{Calculating uncertainty}

The calculation of uncertainty is a fundamental stage in developing an emissions inventory because of the variety of data that must be managed and the wide range of information sources. Therefore, uncertainty values have been established for each of the calculations. For the emission factors and data obtained from the EMEP/EEA (2009) and IPCC (2006), we used the uncertainty values provided by those methodologies.
Frequently, the uncertainty data on quantities or inputs and outputs cannot be derived from the information available because there is only one source of information that provides the average value without information about the uncertainty of that value (Frischknecht et al., 2007). For this type of information, the uncertainty was estimated by following the matrix proposed by Frischknecht et al. (2007) and adapted by Gallego et al. (2009). This matrix had been used in Chile by Muñoz et al. (2015) and defines uncertainty in relation to the reliability, temporality and geography parameters. 
Frischknecht et al. (2007) also establish basic uncertainty factors in association with the demand for energy, transportation, waste management, resource consumption, and the emissions of water, air and soil contaminants. The values that are established will vary if the emissions, demand or consumption are generated during a process, by combustion, or by agriculture (Gallego et al., 2009). In the latter case,
Frischknecht et al. (2007) propose basic uncertainty values $\left(\mathrm{U}_{\mathrm{b}}\right)$ of 1.2 for contaminant emissions $\left(\mathrm{CO}_{2}\right.$, $\mathrm{NH}_{3}, \mathrm{~N}_{2} \mathrm{O}$, etc.) from agriculture and 1.5 for the sources of energy used in agricultural activities. Uncertainty values for reliability $\left(U_{1}\right)$, temporality $\left(\mathrm{U}_{2}\right)$, geography $\left(\mathrm{U}_{3}\right)$ and basic uncertainty $\left(\mathrm{U}_{\mathrm{b}}\right)$ are used to calculate the square of the standard geometric deviation (95\% confidence interval) with Equation 1.

$\sigma_{g}^{2}=\exp \sqrt{\left[\ln \left(U_{1}\right)\right]^{2}+\left[\ln \left(U_{2}\right)\right]^{2}+\left[\ln \left(U_{s}\right)\right]^{2}+\left[\ln \left(U_{b}\right)\right]^{2}}$

The uncertainties for each inventory datum, scientific article or assumption were calculated by using the uncertainty factors (Table 3) and Equation 1.

Once the data uncertainties and emission factors were calculated for each category, the uncertainties of the total $\mathrm{NH}_{3}$ emissions were calculated for the inventory by using the propagation of error methodology proposed by the IPCC (2006). This methodology was used because there is sufficient information about data uncertainty, emission factor averages and standard deviations, and the equations for combining inputs to obtain $\mathrm{NH}_{3}$ emissions. These factors are the primary requirements of the IPCC (2006) for applying the methodology. The propagation of error equation provides two rules for combining uncertainties for multiplication and addition. In the first case, when combining multiplications, Equation 2 is used. In this equation, $U_{i}$ represents the percentage of uncertainty associated with each of the quantities and $U_{\text {total }}$ is the percentage of uncertainty in the product of the quantities.

$$
U_{\text {total }}=\sqrt{U_{1}^{2}+U_{2}^{2}+U_{3}^{2} \ldots+U_{n}^{2}}
$$

Equation 3 is used when uncertain quantities have to be combined by adding or subtracting. In this equation, the $\mathrm{U}_{\text {total }}$ is the percentage of uncertainty in the product of the quantities, $\mathrm{U}_{\mathrm{i}}$ corresponds to the percentage of uncertainty associated with each quantity, and $x_{i}$ are the uncertain quantities.

$$
U_{\text {total }}=\frac{\sqrt{\left(U_{1} \cdot X_{1}\right)^{2}+\left(U_{2} \cdot X_{2}\right)^{2}+\ldots+\left(U_{n} \cdot X_{n}\right)^{2}}}{\left|X_{1}+X_{2}+\ldots+X_{n}\right|}(3)
$$




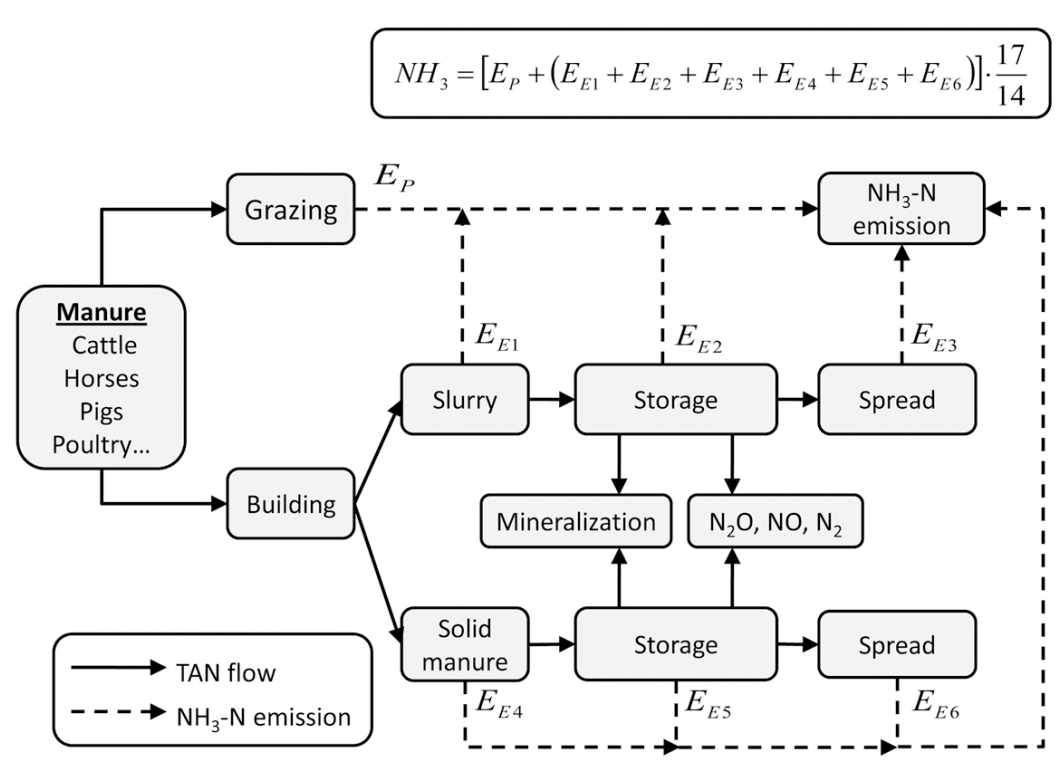

Figure 1. Nitrogen flows in the manure management system.

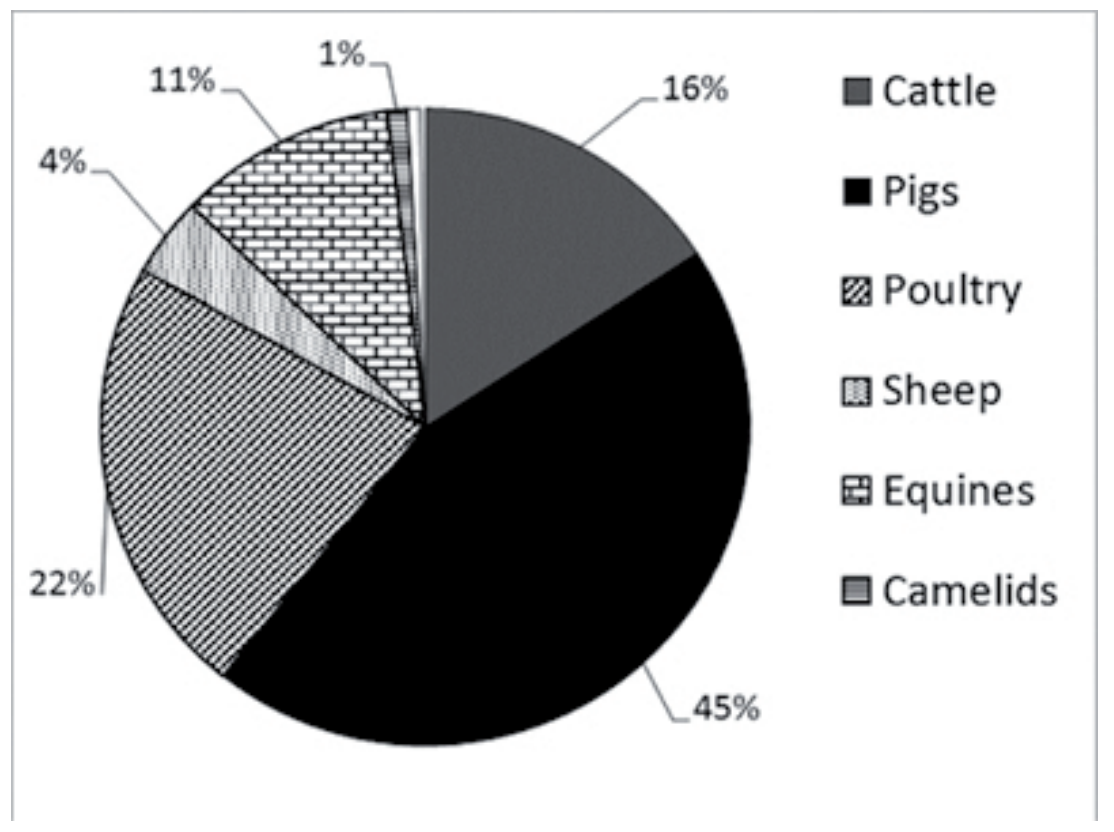

Figure 2. Percentage distributions of $\mathrm{NH}_{3}$ emissions in Chile for different livestock in 2013. 


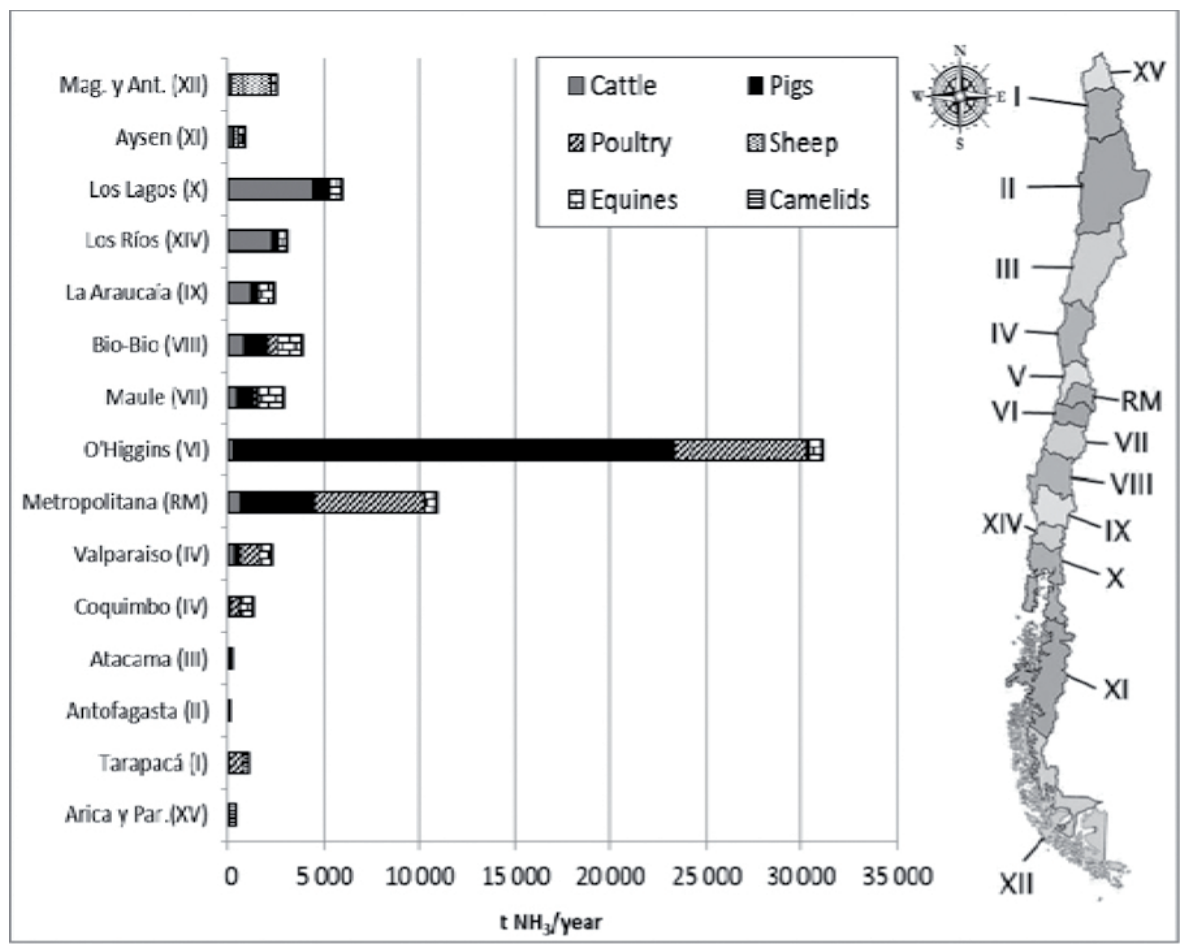

Figure 3. Contribution of $\mathrm{NH}_{3}$ emissions by different livestock by region in Chile, 2013.

\section{Results and Discussion}

\subsection{Distribution of $\mathrm{NH}_{3}$ emissions by type of livestock}

In 2013, the livestock emissions totaled $69,148 \mathrm{t}$ $\mathrm{NH}_{3}$. The origins of these emissions were primarily pigs $(46 \%)$, beef poultry $(22 \%)$, cattle $(16 \%)$, equine animals (11\%) and sheep (4\%) (Figure 2). The remaining quantified livestock (camelids, goats, rabbits, boar and deer) contributed just $1 \%$ of livestock emissions in Chile. In the case of pigs, $73 \%$ of emissions correspond to fattening pigs, and this category contributes $33 \%$ of livestock emissions nationally. However, most authors have identified cattle as the primary source of $\mathrm{NH}_{3}$ emissions (Carew, 2010; Gallego et al., 2009; Webb and Misselbrook,
2004), a trend that is common in the majority of countries (EEA, 2009).

In the case of Chile, where cattle emissions are 10.9 kt $\mathrm{NH}_{3}$ annually (Table 4), cattle represent the third most important source of $\mathrm{NH}_{3}$. In this category, $68.2 \%$ (10.6 $\mathrm{kt} \mathrm{NH}_{3}$ /year) of emissions are generated by dairy cows and the remaining $31.8 \%$ comes from meat production. Within dairy livestock, milk animals contribute the greatest emissions, at $65.2 \%$ of the total (4.9 $\mathrm{kt} \mathrm{NH}_{3}$ /year). In beef production, $60.5 \%$ of emissions are generated by nurse cows, heifers and young bulls. In terms of the distribution of emissions during grazing and housing, there are significant differences at the national level because the degree of confinement varies throughout the country. For example, in the Valparaíso, Metropolitan 
and O'Higgins regions, dairy cows are housed for approximately 270 days/year, such that $69 \%$ of their emissions occur during housing and 31\% occur during grazing. In the Bio-Bio Region, dairy cows are confined for approximately 131 days of the year, generating $46 \%$ of their emissions during housing and $54 \%$ during grazing. In regions further to the south, such as La Araucanía, Los Ríos and Los Lagos, dairy cows are confined for approximately 44 days per year, generating $20 \%$ and $80 \%, 39 \%$ and $61 \%$, and $41 \%$ and $59 \%$ of their emissions occur during housing and grazing, respectively. This trend of higher $\mathrm{NH}_{3}$ emissions within housing is expected and occurs in most countries (EEA, 2009).

In housing, the highest $\mathrm{NH}_{3}$ emissions are generated during ground applications of slurry $\left(\mathrm{E}_{\mathrm{E} 6}\right)$ and manure $\left(E_{E 3}\right)$, for totals of $21 \%$ and $24 \%$, respectively. The lowest emissions during housing occur during the storage stage, with $6 \%$ for solid manure $\left(\mathrm{E}_{\mathrm{E} 5}\right)$ and $10 \%$ for the slurry $\left(\mathrm{E}_{\mathrm{E} 2}\right)$. This trend occurs because part of the TAN is mineralized during storage and another part is transformed into $\mathrm{N}_{2} \mathrm{O}, \mathrm{NO}$ and $\mathrm{N}_{2}$.

In poultry production, which is the second largest source, at $15.5 \mathrm{kt} \mathrm{NH}_{3}$ year $^{-1}$, the livestock are always confined. The greatest source of emissions in this group is broilers, with $71 \%$ of $\mathrm{NH}_{3}$ emissions and 34.7 million heads in 2013, followed by egg layers, with $29 \%$. In this category, the principal emissions are generated during manure application $(51 \%)$ followed by the deposit of manure in housing $(40 \%)$. The remaining $9 \%$ is generated during manure storage.

\subsection{Geographic distribution of emissions}

Similar to the results obtained in Canada by Carew (2010), livestock emissions vary greatly throughout Chile (Figure 3). Out of all Chile's emissions, the largest percentage is generated in the O'Higgins Region (45\%), followed by the Metropolitan Region
(16\%), Los Lagos (9\%) and Bio-Bio (6\%) (Figure 3 and Table 4). The results for the O'Higgins Region are strongly influenced by pig production (Figure $3)$. In 2013, pig production in Chile consisted of 2.9 million heads and was concentrated in the O'Higgins Region, which had $74 \%$ of national production. For this reason, the O'Higgins Region contributes the largest quantity of $\mathrm{NH}_{3}$ emissions from livestock in Chile. In O'Higgins, more than 2 million heads of fattening pigs contribute $55 \%$ of the region's emissions, broiler chickens account for $21 \%$ and pigs used for reproduction represent $17 \%$. In terms of the distribution of pig emissions, $100 \%$ originates in housing because their production is completely confined. This situation is quite different from that which occurs with cattle because the degree of confinement varies greatly depending on the geographic location of the livestock.

For cattle, the highest emissions are generated in central-southern Chile, where the Los Lagos, Los Ríos, Bio-Bio and La Araucanía regions contribute the most, at $41 \%, 21 \%, 11 \%$ and $8 \%$, respectively. In general, grazing emissions tend to be lower than those generated during housing. This trend occurs because the $\mathrm{NH}_{4}-\mathrm{N}$ in urine is deposited directly onto the pasture and rapidly absorbed by the soil, preventing volatilization. During housing, the $\mathrm{NH}_{3}$ emission factors increase with the number of days in confinement, a relation that has been put forth by the European Environmental Commission (2009). In this sense, the livestock emissions per animal in central-southern Chile (from the Bio-Bio Region to the Magallanes Region) are significantly lower than the emissions generated in the northern part of the country. This fact is important if one considers that the national emissions inventories conducted by governments generally use less sophisticated methods (Level 1) based on emissions factors per animal such as $39.3 \mathrm{~kg} \mathrm{NH}_{3} /$ animal/year (EEA, 2009). However, 
this value varies significantly depending on the production strategy in each region and the size of the animal. The latter aspect could be important for the competitiveness of the livestock industry in centralsouthern Chile, particularly because the international trend is moving towards environmental product declarations (EPD) with quantitative information about product environmental performance over the life cycle. In this sense, production systems with lower degrees of confinement would generate a smaller environmental impact in categories such as eutrophication and acidification

In Chile, the emissions per animal are highest in the north and lowest in the south. This trend occurs because there is more intensive grazing in the regions of central-southern Chile, and only some livestock groups (dairy) are housed for prolonged periods of time (Smith et al., 2002). By contrast, milk production systems in northern Chile with intensive confinement are predominant (Carrillo et al., 2011). Therefore, each zone influences the emissions of ammonia, and $\mathrm{NH}_{3}$ emission factors have been determined to vary significantly by zone and their respective production characteristics (Table 5).

Although the degree of confinement is a determinant of the quantity of ammonia emissions, this information is not included in Chile's national statistics. In this sense, the precision of the results could be significantly improved if the National Agriculture and Livestock Census were to incorporate information about the days of animal confinement

\subsection{Uncertainty of the results}

Based on the data analysis, the national emissions of ammonia have an uncertainty of $\pm 45 \%$ as shown in
Table 4; in other words, $69.1 \pm 31.1 \mathrm{kt} \mathrm{NH}_{3} /$ year. The highest uncertainties occur for the goat $( \pm 81.6 \%)$, deer $( \pm 77.1 \%)$ and camelid $( \pm 76.7 \%)$ categories. However, these uncertainties do not significantly affect the final result because of the low contribution to $\mathrm{NH}_{3}$ emissions from these categories. Perhaps the most important result is for cattle, with an uncertainty of $\pm 55.4 \%$ (6.06 kt NH $\mathrm{NH}_{3}$ year). This category is heavily influenced by beef cattle, with uncertainties of up to $84 \%$, primarily because of uncertainties related to the $\mathrm{N}$ excreted per animal (52\%) and $\mathrm{N}$ emission factors from TAN that are available in grazing $(60 \%)$. There is high uncertainty for excreted $\mathrm{N}$ because its value is the production of the $\mathrm{N}$ excretion rate (IPCC, 2006) and the average mass per animal. Both values are obtained from published sources and combined to obtain the uncertainty of excreted N. In this category, individual uncertainties become increasingly important because of the smaller quantity of calculation operations (equations) required to quantify the final emissions of $\mathrm{NH}_{3}$. Undoubtedly, determining the $\mathrm{N}$ excreted per animal and local (regional) emission factors of $\mathrm{N}$ from the available TAN would greatly improve the certainty of the results included in national inventories. In the case of dairy animals, which have an uncertainty that is close to $44 \%$, the primary sources of uncertainty are the $\mathrm{N}$ excreted per animal, the $\mathrm{N}$ emission factors from TAN during the manure and slurry management stages, and the degree of animal confinement. As in the case of livestock for meat production, determining the excreted $\mathrm{N}$ per animal and the $\mathrm{N}$ emission factors from the available TAN would greatly improve the certainty of the results. Along with these parameters, the degree of animal confinement should be included in national livestock surveys (censuses). 
Table 4. National inventory of $\mathrm{NH}_{3}$ emissions from livestock by region for 2013 in Chile

\begin{tabular}{|c|c|c|c|c|c|c|c|c|c|c|c|c|c|c|c|c|c|c|}
\hline & \multicolumn{15}{|c|}{$\mathrm{NH}_{3}$ emissions from Chile by region ${ }^{2}(\mathrm{t} \mathrm{NH} /$ year) } & \multirow{2}{*}{ Total } & \multirow{2}{*}{$\begin{array}{c}\text { Unc. } \\
\text { (t } \mathrm{NH}_{3} / \text { year) }\end{array}$} & \multirow{2}{*}{$\begin{array}{l}\text { Unc. } \\
(\%)\end{array}$} \\
\hline & XV & $\mathbf{I}$ & II & III & IV & $\mathbf{v}$ & M & VI & VII & VIII & IX & XIV & $\mathrm{X}$ & XI & XII & & & \\
\hline Cattle & - & - & - & - & - & 352 & 635 & 309 & 433 & 882 & 1,208 & 2,270 & 4,448 & 236 & 165 & 10,939 & $\pm 6,058$ & \pm 55.4 \\
\hline Pigs & 24 & 40 & 52 & 39 & 105 & 211 & 3,881 & 23,062 & 872 & 1,206 & 331 & 356 & 829 & 28 & 17 & 31,056 & $\pm 12,210$ & \pm 39.3 \\
\hline Poultry & - & 771 & - & - & 441 & 1,025 & 5,739 & 6,934 & 163 & 462 & 12 & - & - & - & - & 15,545 & $\pm 8,321$ & \pm 53.5 \\
\hline Sheep & 21 & 0 & 0 & 0 & 0 & 0 & 0 & 139 & 90 & 42 & 39 & 35 & 51 & 276 & 2,077 & 2,769 & \pm 564 & \pm 20.4 \\
\hline Equine & 9 & 5 & 17 & 119 & 695 & 661 & 599 & 655 & 1,319 & 1,249 & 754 & 348 & 556 & 298 & 248 & 7,532 & $\pm 2,929$ & \pm 38.9 \\
\hline Camelid & 339 & 252 & 55 & 1 & 3 & 3 & 1 & 5 & 4 & 2 & 11 & 8 & 8 & 2 & 5 & 698 & \pm 536 & \pm 76.7 \\
\hline Goats & 5 & 2 & 5 & 19 & 240 & 29 & 7 & 12 & 24 & 24 & 24 & 8 & 9 & 10 & 0 & 417 & \pm 340 & \pm 81.6 \\
\hline Rabbits & 2 & 15 & 19 & 6 & 6 & 6 & 13 & 12 & 3 & 7 & 5 & 1 & 2 & 0 & 0 & 98 & \pm 41 & \pm 42.0 \\
\hline Wild boar & - & - & 0 & - & 0 & - & 2 & - & 2 & 8 & 10 & 7 & 9 & 0 & - & 39 & \pm 28 & \pm 72.7 \\
\hline Deer & - & - & - & - & - & 0 & - & - & 5 & 2 & 6 & 1 & 40 & - & - & 54 & \pm 42 & \pm 77.1 \\
\hline Total & 400 & 1.085 & 148 & 183 & 1.492 & 2.287 & 10.877 & 31.128 & 2.914 & 3.885 & 2.401 & 3.034 & 5.951 & 850 & 2.513 & & & \\
\hline (\%) & 0.6 & 1.6 & 0.2 & 0.2 & 2.2 & 3.3 & 15.7 & 45.0 & 4.2 & 5.6 & 3.8 & 4.4 & 8.6 & 1.2 & 3.6 & & & \\
\hline
\end{tabular}

a XV: Arica y Parinacota; I: Tarapacá; II: Antofagasta; III: Atacama; IV: Coquimbo; V: Valparaíso; M: Metropolitana; VI: O’Higgins; VII: Maule; VIII: Bío-Bío; IX: La Araucanía; XIV: Los Lagos; X: Los Ríos; XI: Aysén; XII: Magallanes y Antártica. Unc.: Uncertainty

Table 5. $\mathrm{NH}_{3}$ emission factors for cattle for the different Chilean regions (zones) and animal weights

\begin{tabular}{|c|c|c|c|c|c|}
\hline \multirow{2}{*}{ Dairy cows } & \multicolumn{5}{|c|}{ Regions $\left(\mathrm{kg} \mathrm{NH}_{3}\right.$ animal $^{-1}$ year $^{-1}$ ) } \\
\hline & $\mathrm{V}$ & VI VII & VIII & IX & XIV $\mathrm{X}$ \\
\hline Cows $(400 \mathrm{~kg})$ & & 29.2 & 16.8 & & 9.0 \\
\hline Cows $(300 \mathrm{~kg})$ & & 21.9 & 12.6 & & 6.8 \\
\hline Calves $(207 \mathrm{~kg})$ & & 15.1 & 8.7 & & 4.7 \\
\hline
\end{tabular}

\section{Conclusions}

This analysis has provided the basis for determining the principal sources of $\mathrm{NH}_{3}$ emissions from livestock in Chile and their geographic distribution. Thus, it was determined that livestock emission sources vary greatly throughout Chile, with large differences among emission quantities by region and the livestock sources that generate them. The total emissions for 2013 were estimated to be $69.1 \mathrm{kt} \mathrm{NH}_{3}$, with the largest portion coming from the O'Higgins Region, which generates $45 \%$ of the total livestock emissions in the country. Pig production is the primary source of emissions by animals, with $45 \%$ of the national 
total. Cattle represent the third most important source nationally, and their $\mathrm{NH}_{3}$ emissions vary greatly by geographic location, although they are concentrated primarily in central-southern Chile. The primary regional differences are related to variations in livestock management systems, in that the degree of animal confinement strongly influences $\mathrm{NH}_{3}$ emission factors and the confinement level increases successively from the north to the south of the country. Thus, it was determined that the $\mathrm{N}$, the $\mathrm{N}$ emission factors excreted from TAN available during manure and slurry management and the degree of animal confinement are the primary sources of uncertainty, for a total of $44.9 \%$ of the national livestock inventory. This percentage could be significantly reduced if regional emission factors are developed and if the degree of animal confinement is included in the information gathered as part of the national statistics in Chile, such as the Agriculture, Livestock and Forestry Census.

\section{Acknowledgments}

The authors are grateful for financial support from FONDEF Project D07I1096 from CONICYT, Chile.

\section{References}

Alfaro, M., Salazar, F., Endress, D., Dumont, J., Valdebenito, B. 2006. Nitrogen leaching losses on a volcanic ash soil as affected by the source of fertiliser. R.C. Suelo Nutr. Veg. 6(2), 54-63.

Buijsman, E., Maas, H.F.M., Asman, W.A.H. 1987. Anthropogenic $\mathrm{NH}_{3}$ emissions in Europe. Atmospheric Environment. 21, 1009-1022.

Carew, R., 2010. Ammonia emissions from livestock industries in Canada: Feasibility of abatement strategies. Environmental Pollution. 158, 2618-2626.
Carrillo, B., Moreira, V., González, J., 2011. Characterization and classification of dairy productive systems in the Central-South region of Chile: a multivariate analysis. IDIESA. 29(1), 71-78.

Doorn, M.R.J., Natschke, D.F., Thorneloe, S.A., Southerland, J., 2002. Development of an emission factor for ammonia emissions from US swine farms based on field tests and application of a mass balance method. Atmospheric Environment. $36,5619-5625$

EMEP/EAA. 2009. Air pollutant emission inventory guidebook - 4.B Animal husbandry and manure management. Available at http://www.eea.europa. eu/publications/emep-eea-emission-inventoryguidebook-2009

Frischknecht R., Jungbluth N., Althaus H.J., Doka G., Heck T., Hellweg S., Hischier R., Nemecek T., Rebitzer G., Spielmann M., Wernet G. 2007. Overview and Methodology. Ecoinvent report $N^{\circ} 1$. Swiss Centre for Life Cycle Inventories. Dübendorf.

Gac, A., Béline, F., Bioteau, T., Maguet, K., 2007. A French inventory of gaseous emissions $\left(\mathrm{CH}_{4}\right.$, $\mathrm{N}_{2} \mathrm{O}, \mathrm{NH}^{3}$ ) from livestock manure management using a mass-flow approach. Livestock Science. $112,252-260$

Gallego, A., Hospido, A., Moreira, M.T., Feijoo, G. 2009. Quantification of eutrophic aerial compounds in Galicia (NW Spain): Part $1-\mathrm{NH}_{3}$ inventory. Atmósfera. 22(2), 141-160.

Groot Koerkamp, P.W.G. 1994. Review on emissions of ammonia from housing systems for laying hens in relation to sources, processes, building design and manure handling. Journal of Agricultural Engineering Research. 59, 73-87. 
INE, 2007. VII Censo agropecuario y forestal. Cuadro

12: Existencia de ganado en las explotaciones agropecuarias y forestales por especie según región, provincia y comuna.

INE, 2013a. Encuesta de criaderos de cerdo - I semestre 2013. Cuadro 2.15: Existencia de cerdos, reproductores por sexo y de engorda por tipo, según período y región.

INE, 2013b. Encuesta de criaderos de aves - I semestre 2013. Cuadro 1.11 y 1.12 .

INE, 2013c. Encuesta ganado ovino 2013. Cuadro 5: Existencia de ganado ovino por raza, según región y provincia.

INE, 2013d. Encuesta ganadería caprina 2013. Cuadro B1: Existencia de ganado caprino, según región. 2007, 2010 y 2013.

INE, 2013e. Encuesta de ganado bovino 2013. Cuadro 7: Existencia de ganado bovino de lechería por categoría según región y provincia 2013. Cuadro 8. Existencia de ganado bovino para carne por categoría, según región y provincia.

IPCC, 2006. Chapter 10: Emissions from Livestock and Manure Management, section 10.2.

Luengo, J., Morales, M.A., 1999. Índice de carnosidad bruta (ICB) de canales bovinos por razas, según clase y categorías, de acuerdo a la actual normativa chilena de tipificación de carnes. Avances en Ciencias Veterinarias. 14(1-2), 5-12.

Martínez-Lagos, J., Salazar, F., Alfaro, M., Misselbrook, T.H. 2010. Inventory of ammonia emission from livestock production in Los Lagos and Los Ríos regions, Chile. Chilean Journal of Agricultural Research. 70(1), 95-103.

Martínez-Lagos, J., Salazar, F., Alfaro, M., Rosas, M., Macías, F. 2015. Nitrogen mineralization in a silandic andosol fertilized with dairy slurry and urea. Journal of Soil Science and Plant Nutrition. 15(1), 60-75.
Muñoz, E., Vargas, S., Navia, R. 2015. Environmental and economic analysis of residual woody biomass transport for energetic use in Chile. Int J Life Cycle Assess. 20(7), 1033-1043.

Muñoz, C., Paulino, L., Monreal, C., Zagal, E., 2010. Greenhouse gas $\left(\mathrm{CO}_{2}\right.$ and $\left.\mathrm{N}_{2} \mathrm{O}\right)$ emissions from soils: A review. Chilean Journal of Agricultural Research. 70(3), 485-497.

Nájera, F., Tapia, Y., Baginsky, C., Figueroa, V., Cabeza, R., Salazar, O., 2015. Evaluation of soil fertility and fertilisation practices for irrigated maize (Zea mays L.) under Mediterranean conditions in central Chile. Journal of Soil Science and Plant Nutrition. 15(1), 84-97.

Pain, B.F., Misslebrook, T.H., Jarvis, S.C., Chambers, B.J., Smith, K.A., Webb, J. 1999. Inventory of Ammonia Emission from UK Agriculture, 1997. Report of MAFF contract WAO630. IGER, North Wyke.

Ryden, J.C., Whitehead, D.C., Lockyer, D.R., Thompson, R.B., Skinner, J.H., Garwood, E.A., 1987. Ammonia emission from grassland and livestock production systems in the UK. Environmental Pollution. 48, 173-184.

Smith, R., Moreira, V., Latrille, L. 2002. Characterization of dairy productive systems in the Tenth Region of Chile using multivariate analysis. Agricultura Técnica. 62(3), 375-395.

Sotiropoulou, R.E.P., Tagaris, E., Pilinis, C. 2004. An estimation of the spatial distribution of agricultural ammonia emissions in the Greater Athens Area. Science of the Total Environment. 318(1-3), 159-169.

Webb, J., 2001. Estimating the potential for ammonia emissions from livestock excreta and manures. Environmental Pollution. 111, 395-406. 
Webb, J., Misselbrook, T.H., 2004. A mass-flow model of ammonia emissions from UK livestock production. Atmospheric Environment. 38, 2163-2176.
Xu, P., Zhang, Y., Gong, W., Hou, X., Kroeze, C., Gao, W., Luan, S., 2015. An inventory of the emission of ammonia from agricultural fertilizer application in China for 2010 and its high-resolution spatial distribution. Atmospheric Environment. 115, 141148. 